\title{
The SAICA SYLlabus for ETHICS: DOES IT ALL ADD UP?
}

GJ Rossouw

Philosophy Department, University of Pretoria

\begin{abstract}
The South African Institute for Chartered Accountants (SAICA) recently (2005) announced guidelines for a syllabus for Ethics that is to be included in the undergraduate studies of students studying towards the Chartered Accountant (CA) qualification. The purpose of this paper is to make a critical comparison between the objectives and the outcomes of the SAICA Ethics syllabus to determine whether the proposed outcomes match the proposed objectives. A teaching-learning competency framework for applied ethics will be introduced first, to provide a theoretical framework within which the stated comparison between the proposed objectives and outcomes of the Ethics syllabus can be carried out.
\end{abstract}

Abstract

JEL D83, I21

\section{1}

\section{Introduction}

The South African Institute for Chartered Accountants (SAICA) recently (2005) announced guidelines for a syllabus for Ethics that is to be included in the undergraduate studies of students studying towards the Chartered Accountant (CA) qualification. The proposed Ethics syllabus is one of eight support subjects that prospective CA candidates have to study in addition to their four core subjects.

The proposed Ethics semester course (or alternatively two half-semester courses) is divided into three broad themes: (1) Introduction to Applied Ethics (2) Business Ethics and (3) Ethics and Accountancy. Outcomes for each of these three themes are stipulated and some suggestions are made as to how the course could be taught and assessed.

The purpose of this paper is to make a critical comparison between the objectives and the outcomes of the SAICA Ethics syllabus to determine whether the proposed outcomes match the proposed objectives. A teachinglearning competency framework for applied ethics will be introduced first, to provide a theoretical framework within which the stated comparison between the proposed objectives and outcomes of the Ethics syllabus can be carried out.

2

\section{A teaching-learning competency framework for applied ethics}

Basing his approach on a review of approaches to the teaching of applied ethics, Rossouw (2002; 2004) developed a Teaching-Learning Competency (TLC) framework for applied ethics, in which he distinguishes between three possible positions in response to the question: 'What do you want to achieve in teaching applied ethics?' The three positions discerned by Rossouw are cognitive competence, behavioural competence and managerial competence respectively. Within each of these positions he identifies (a) the purpose of teaching applied ethics (b) the competencies (or outcomes) associated with that purpose and (c) the teaching-learning methods typically used to achieve these competencies. Each of these three positions on teaching applied ethics will be briefly explained. 


\subsection{The cognitive competence position}

In the position of cognitive competence, the purpose of teaching is to acquire the intellectual knowledge and skills to identify, understand, analyse and judge applied ethical matters (cf. Shaw, 1996: 493). The emphasis is thus on both the theoretical constructs that have to be learned to identify, understand and analyse ethical matters and the intellectual skills needed if this knowledge is to be applied in the assessment and analysis of ethical matters.

The competencies that learners have to acquire when assuming the cognitive competence position are (see Table 1 below):

Awareness of the ethical dimension: Learners need to discover and become aware of the ethical dimension and typical ethical issues in their field or profession (cf. Rabouin, 1997: 249).

Ethical vocabulary and theories: Learners should be familiar with the ethical concepts, frameworks, models and theories that apply to their field or profession (cf. Mahoney 1990: 67; McDonald \& Donleavy 1995: 841; Hosmer 1998: 10; Solberg, Strong \& McGuire 1995: 76).

Moral reasoning: Learners should cultivate the ability to analyse, compare and assess different ethical perspectives. They must develop the independence of mind to make an own assessment of ethical issues within their field or profession (cf. Paine, 1991: 78; Solberg, Strong \& McGuire 1995: 78).

Ethical decision-making: Learners must be familiar with approaches to ethical decisionmaking and ethical dispute resolution and be able to apply them to ethical issues in their field or profession.

Tolerance of moral differences: Learners must be able to endure moral ambiguity and to tolerate moral positions that differ from their own (Mahin, 1998: 74).

Table 1

Cognitive competence

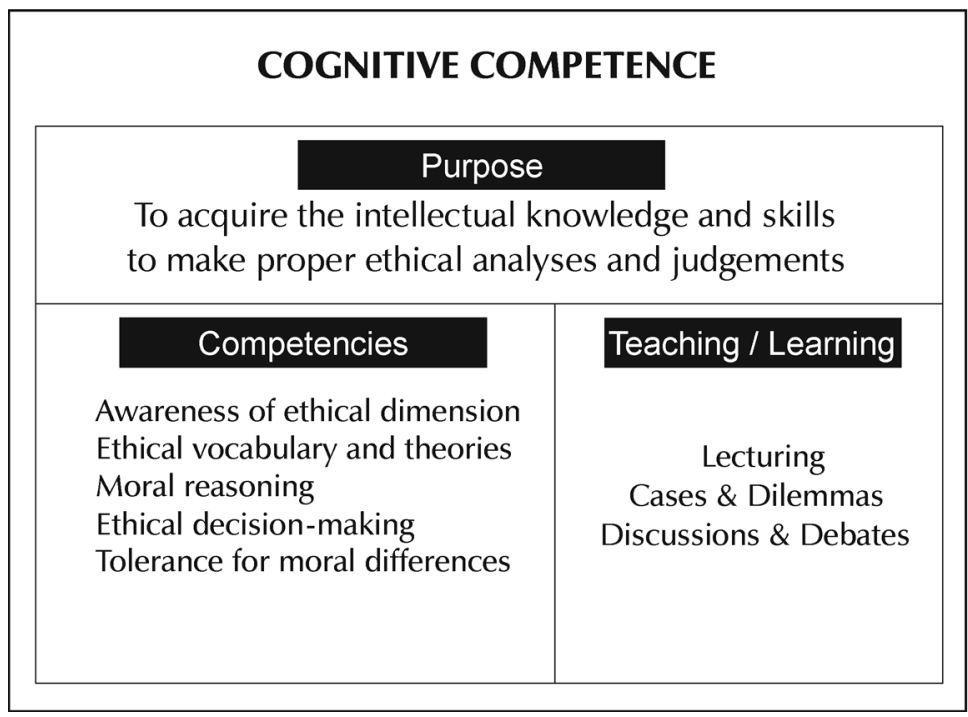

The teaching-learning methods that would typically be used to develop these competencies are, first, lecturing, when theoretical concepts, frameworks, models and theories are introduced to learners. Such lecturing would, however, have to be complemented by learning opportunities, in which learners could develop the intellectual skill of applying theoretical knowledge to specific issues within their field or profession. The analysis and assessment of specific case studies and ethical dilemmas as well as class discussions and class debates could be used to 
create learning opportunities in which reasoning and decision-making skills can be cultivated (cf. Shaw, 1996: 494; Solberg, Strong \& McGuire, 1995: 77). The same learning opportunities could also facilitate the development of tolerance of moral differences (cf. Piper et al., 1993: 53).

\subsection{The behavioural competence position}

The behavioural competence position regards the purpose of teaching applied ethics as the cultivation of commitment and will to act according to ethical convictions. It is premised on the assumption that cognitive competence, that is, theoretical knowledge and intellectual skills, is not sufficient to ensure that learners are going to be willing and able to behave morally (cf. Coles, 1995: 68). To achieve the latter, intrapersonal moral development has to be facilitated in learners (Whetstone, 1998: 188).

If applied ethics is to be taught in a manner that will facilitate behavioural competence in learners, the following competencies have to be developed (see Table 2 below):

Moral sensitivity: Learners need to be sensitive to the effect their behaviour is likely to have on other persons (cf. Shaw, 1996: 498).

Moral imagination: Learners should be able to imagine how other persons are likely to experience specific ethical or unethical behaviour and also to imagine ethical alternatives to current situations (cf. Anderson, 1997: 287-288; Werhane, 1999: 89-108).

Moral courage: Learners should develop the determination to act on their moral convictions even when it is neither convenient nor self-serving to do so (cf. Piper et al., 1993: 49; McDonald \& Donleavy, 1995: 841-842; Rabouin, 1997: 255; Maclagan, 1998: 24; Mahoney, 1999).

Moral virtues: Learners must develop those characteristics (virtues) that will dispose them to act ethically within their field or profession.

Table 2

Behavioural competence

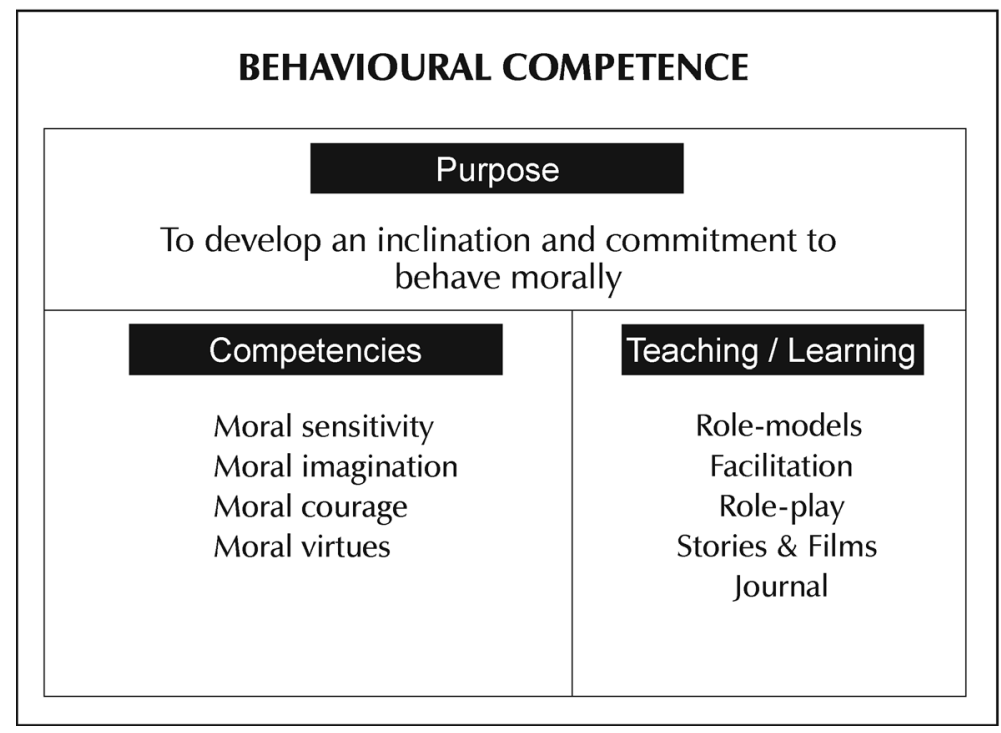

The teaching-learning methodologies that can be used to facilitate the acquisition of behavioural competence differ substantially from those used to facilitate cognitive competence. Lecturing would play a minor role in teaching for behavioural competence, because there would be a greater focus on the facilitation of affective and volitional change in learners. Teaching-learning methods like role-play, engagement with role-models, the use of stories and films and keeping personal 
learning journals can be used to facilitate learning opportunities conducive to intrapersonal moral development (cf. Adams et al., 1998: 1327-1328; Binns, 1994: 178; Berger \& Pratt, 1998; Coles, 1989: 204-205; Paine, 1991: 81; Sims, 2002: 181; Solberg, Strong \& McGuire 1995: 78).

\subsection{The managerial competence position}

The managerial competence position regards the purpose of teaching applied ethics as equipping learners with the ability to direct and control the ethical performance of and within organisations. It is premised on the assumption that neither cognitive nor behavioural competence alone or in combination is sufficient for managing the ethical performance of organisations. The management of organisational ethics performance is a specialised field that in turn requires specialised knowledge and skills (cf. Rossouw, 2004: 40).

The competencies that learners should develop in order to acquire managerial competence are listed below (see Table 3):
Ethical leadership: Learners must develop the vision and intent to take a leading role in enhancing moral performance within their field or profession (cf. Piper et al., 1993: 119).

Strategic importance of ethics for organisations: Learners have to develop insight into the strategic importance of ethics in organisations. They have to be able to make a convincing case for ethics based on strategic considerations within their field or profession.

Organisational ethics: Learners need to develop insight into the dynamics and demands of ethics within organisational contexts. They must also be able to deal with the systemic nature of ethics within organisations or professions (cf. Fudge \& Schlachter, 1999: 296; Nielsen, 1998: 585).

Governance of ethics: Learners must be able to direct and control the ethical performance of organisations. Further, they need to acquire the ability to institutionalise ethical standards within organisations or professions (McDonald \& Donleavy, 1995: 842; Nielsen, 1998: 585; Stiles et al., 1993: 246).

Table 3

Managerial competence

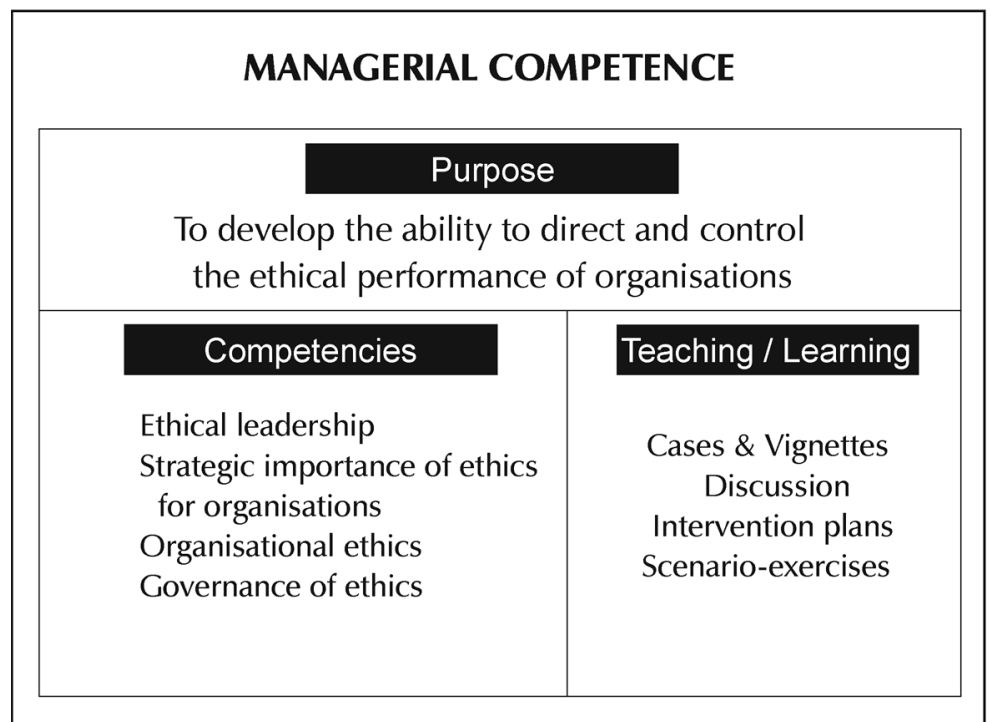


The teaching-learning methodologies associated with managerial competence will include lecturing, but will also go beyond this, as learning opportunities must be created to facilitate the ability to manage ethics within organisations or professions. Discussion of case studies or vignettes, and the development of management scenarios or management interventions to change the moral direction or performance of organisations can be used to facilitate managerial competence in learners (cf. Paine, 1991: 82; Piper et al., 1993: 122; Adams et al., 1998: 1327-1328).

Against the backdrop of the above teachinglearning competency framework for applied ethics, the objectives and outcomes of the new SAICA syllabus for Ethics will be discussed.

\section{3}

\section{Objectives of the ethics course}

The objectives of the SAICA ethics syllabus are not stated explicitly in the guidelines provided by SAICA (2005). However, in the introductory discussion to the Ethics syllabus, three objectives have a cursory mention (cf. SAICA, 2005: 21/05). They are:

(a) to provide a foundation of general and specific ethical knowledge;

(b) to provide a background for the study of the professional code of conduct of the SA Institute of Chartered Accountants; and

(c) to equip students for meaningful relationships with people from cultural backgrounds that differ from their own.

There is, however, no indication that the above list of objectives is complete and exhaustive as far as the objectives for the proposed syllabus are concerned. It seems safer to assume that the above list of objectives is incomplete, and that SAICA had further objectives in mind when they introduced the Ethics syllabus.

An indication of further objectives that SAICA might have had in mind when planning and introducing the Ethics syllabus is contained in a report prepared for SAICA by Prozesky (2001): Ethics in the education of South African Chartered Accountants. In this report, the author recommends specific content that should be included in an Ethics course. However, he, too, does not explicitly state what the objectives of such an Ethics course ought to be. In considering academic perspectives on ethics in accountancy education, Prozesky discusses, amongst other things, the view of Mary Beth Armstrong. $\mathrm{He}$ quotes Armstrong as saying that the objectives of an ethics course in Accounting education should be: 'to enhance their moral development, to enable them to think more critically when confronted with moral dilemmas, and to become thinking participants in the profession they will soon be entering' (Armstrong, 1993: 91, in Prozesky, 2001: 15-16). These objectives are, however, mentioned merely as part of Prozesky's general discussion. There is thus no explicit recommendation that the objectives mentioned by Armstrong should be adopted by SAICA as the purpose of their proposed Ethics course.

I wish to argue that SAICA would be in agreement with at least the first two of the objectives stated above by Armstrong, viz.

(a) 'to enhance their [accounting students'] moral development'; and

(b) 'to enable them [accounting students] to think more critically when confronted with moral dilemmas'.

SAICA's probable agreement with these objectives can be suggested because they make it clear in their document The Education Requirements of SAICA for Entry into Part 1 of the Qualifying Examination, that it is integral to their education policy to develop the intellectual skills of professional accountants (5/05) as well as to develop and instil ethical behaviour in professional accountants (7/05).

If we add the two additional objectives proposed by Armstrong (discussed above) to the three objectives mentioned explicitly in the introductory part of the SAICA Ethics syllabus, the following five objectives can be assumed to underpin SAICA's Ethics syllabus:

(a) to enhance moral development;

(b) to think critically when confronted with moral dilemmas;

(c) to provide a foundation of general and specific ethical knowledge; 
(d) to provide a background for the study of the professional code of conduct of the SA Institute of Chartered Accountants; and

(e) to equip students for meaningful relationships with people from cultural backgrounds that differ from their own.

Such a set of objectives would broadly accord with the generic set of objectives that Loeb (1988) identified for teaching accounting ethics. Based on work done earlier by Callahan, Loeb concludes that courses on ethics in accountancy education should have the following objectives:

(a) 'relate accounting education to moral issues;

(b) recognise issues in accounting that have ethical implications;

(c) develop a sense of moral obligation or responsibility;

(d) develop the abilities needed to deal with ethical conflicts or dilemmas;

(e) learn to deal with the uncertainties of the accounting profession;

(f) set the stage for a change in ethical behaviour; and

(g) appreciate and understand the history and composition of all aspects of accounting ethics and their relationship to the general field of ethics' (Loeb, 1988: 322).

This supposed set of objectives is also broadly in alignment with a more recent international development in teaching accounting ethics. On September 7, 2006, the International Accounting Education Standards Board (IAESB) of the International Federation of Accountants (IFAC) published a so-called exposure draft: Approaches to developing and maintaining professional values, ethics, and attitudes (IFAC, 2006). This was circulated for comment to IFAC-affiliated member organisations. In this document, four objectives for ethics education within accounting education are identified (IFAC, 2002: 10-11).

These objectives are:

(a) enhancing ethics knowledge

(b) developing ethical sensitivity

(c) improving ethical judgement

(d) maintaining an ongoing commitment to ethical judgement.

It is further recommended that objectives (a) to (c) be included in the pre-qualification education programme for accountants and that objective (d) be addressed in both preand post-qualification education programmes (IFAC, 2006: 4).

Comparing the supposed objectives of the SAICA ethics syllabus with the objectives articulated in the above IAESB and IFAC proposal, it is clear that they broadly overlap. The only distinct difference between them is that the SAICA syllabus places additional emphasis on coping with diversity within the South African context.

When the objectives of the SAICA ethics syllabus are analysed in terms of Rossouw's Teaching-Learning Competency (TLC) framework, it is clear that the objectives of the SAICA Ethics course fit into the cognitive competence and behavioural competence positions. Using the same numbering for the objectives of the SAICA Ethics course as discussed above, the match between the SAICA Ethics course and the TLC framework is displayed in Table 4 below: 
Table 4

SAICA and TLC framework comparison

\begin{tabular}{|c|c|c|c|}
\hline & \multicolumn{3}{|c|}{ TEACHING -LEARNING COMPETENCY MODEL } \\
\hline & $\begin{array}{c}\text { Cognitive } \\
\text { competence }\end{array}$ & $\begin{array}{l}\text { Behavioural } \\
\text { competence }\end{array}$ & $\begin{array}{l}\text { Managerial } \\
\text { competence }\end{array}$ \\
\hline $\begin{array}{c}\text { Objectives } \\
\text { of } \\
\text { SAICA's } \\
\text { Ethics } \\
\text { Syllabus }\end{array}$ & $\begin{array}{l}\text { (b) To think critically } \\
\text { about moral } \\
\text { dilemmas } \\
\text { (c) To provide } \\
\text { ethical knowledge } \\
\text { (d) To provide a back- } \\
\text { ground for study of } \\
\text { professional code }\end{array}$ & $\begin{array}{l}\text { (a) To enhance } \\
\text { moral development } \\
\\
\text { (e) To equip students } \\
\text { for meaningful } \\
\text { relationships with } \\
\text { people from } \\
\text { different culture }\end{array}$ & \\
\hline
\end{tabular}

\section{4}

\section{Outcomes of the Ethics course}

The semester-long SAICA Ethics course is structured on three themes: (1) Introduction to Applied Ethics (2) Business Ethics and (3) Ethics and Accountancy. Specific outcomes are stipulated for each of these themes. With reference to the TLC framework, the outcomes are comparable to the competencies specified in the model. The outcomes provided for each of the three sections in the SAICA Ethics syllabus are listed below:

\section{Outcomes for the Introduction to Applied} Ethics section:

1. A sound introductory understanding of the ethical dimension of individual and social life in the context of cultural diversity

2. Basic grasp of selected ethical theories and their relevance to business and professional ethical issues

3. Ability to link case material with ethical knowledge and theory
4. Ability to use ethical decision-making strategies, for instance, in relation to case studies (SAICA, 2005: 122/05).

\section{Outcomes for the Business Ethics section:}

1. An introductory understanding of selected, large-scale, socio-economic ethical issues relevant to business and professional practice

2. An introductory understanding of selected issues and approaches in business ethics in South Africa and internationally

3. Knowledge and basic skills relating to the nature of organisations and management in ethical perspective

4. Ability to link the above competencies and knowledge with case studies (SAICA, 2005: 123/05).

\section{Outcomes for the Ethics and Accountancy section:}

1. Knowledge of the nature of professionalism in general and of its ethical aspects 
2. Understanding of the purpose, structures and contents of selected codes of ethics from business and the professions

3. Basic knowledge of main ethical issues and aspects of the accountancy profession

4. Ability to analyse case studies from the accountancy profession in relation to decision-making, comparative and diversity ethics (where appropriate) and ethical theories, and to propose solutions to the ethical issues they involve (SAICA, 2005: 123/05).

\section{Does it all add up?}

When the above sets of outcomes are compared with those of the SAICA syllabus, it is clear that the objectives and outcomes largely match each other. It is also evident that, when most of the objectives fall within the cognitive competence position of the TLC framework, this match becomes even more pronounced as far as the outcomes are concerned. This is because most outcomes could be classified as cognitive competence outcomes. However, in the comparison of the objectives with the outcomes of the SAICA Ethics syllabus, two interesting and significant discrepancies also become evident.

The first significant discrepancy is that, while the SAICA Ethics syllabus makes no reference to managerial competence in the objectives, there is explicit mention of managerial competence outcomes in Business Ethics, specifically in section 2, which states that the $3^{\text {rd }}$ outcome is: 'Knowledge and basic skills relating to the nature of organizations and management in ethical perspective' (SAICA, 2005: 123/05). In the same section, the $4^{\text {th }}$ outcome stipulates that learners should be able to link these competencies and knowledge to case studies (SAICA, 2005: 123/05). It is thus clear that, although managerial competence in terms of both knowledge and skills were not mentioned in the objectives of the SAICA Ethics syllabus, they are nevertheless explicitly referred to in the outcomes.

A second significant discrepancy emerging from the comparison of the objectives with the outcomes of the SAICA Ethics syllabus is that, while behavioural competence was explicitly mentioned in the introduction to the SAICA Ethics syllabus (objective (e) in Table 4 above), and also in their education policy (objective (a) in Table 4 above), no behavioural competencies are mentioned in the outcomes. This discrepancy between the objectives of the course and its outcomes can be interpreted in at least three different ways.

The first interpretation might be that this was an oversight on the part of those who compiled the syllabus and that they simply neglected to stipulate outcomes that both correlate with their objectives and emphasise behavioural competence. Support for such an interpretation could be found in their proposed teaching-learning methodologies. One of the methodologies suggested in the SAICA document is a learning journal. In fact, the document contains an attachment dealing specifically with the composition of such a journal and how it could be used in the Ethics course. In the earlier discussion of the TLC framework, typical methods used to facilitate behavioural competence in learners were referred to. A learning journal was indicated to be one of the teaching methodologies typically associated with the development of behavioural competence (see Table 2 above).

A second interpretation might be that the compilers of the SAICA Ethics syllabus simply assumed that learner acquisition of the necessary cognitive competence would, at the same time, automatically equip them with behavioural competence. This assumption, frequent among educators, is increasingly contested. There is a growing body of evidence that cognitive competence does not necessarily translate into behavioural competence (cf. Bunke, 1988: 7; Coles, 1995: 68; Hosmer, 1988: 10. Piper et al., 1993: 49; McDonald \& Donleavy, 1995: 841-842; Maclagan, 1998: 24; Mahoney, 1999; Rabouin, 1997: 255). In other words, possessing the theoretical knowledge and the intellectual skills to reason out ethical matters does not automatically result in ethical behaviour. This requires more than cognitive competence. It must be complemented by the intrapersonal moral development that will dispose someone to ethical behaviour. 
A third interpretation of the discrepancy between the mention of behavioural competence in the objectives, but not in the outcomes of the SAICA syllabus, might be the compilers' exclusion of behavioural competence outcomes from the SAICA Ethics syllabus because they were not convinced that such outcomes were appropriate for tertiary education. One school of thought holds that university education should be limited strictly to intellectual formation and should avoid character formation. There are, however, equally strong arguments against this position. The latter is advocated on various grounds, but one particularly relevant contention is that university education and professional training are intricately linked. Since their inception into the Western world, universities have been associated with professional training, to the extent that they owe their existence largely to the need for professional training in society. Pelikan (1992: 99) reminds us that the medieval university typically consisted of four faculties, those of Philosophy, Medicine, Jurisprudence and Theology. Three of the four faculties were thus involved in the professional training of doctors, lawyers and clergy respectively. If it is to be acknowledged that professional training falls within the ambit of university education, then it should also be acknowledged that the formation of the professional virtues and identity of aspiring professionals (and thus their behavioural competence) is also a legitimate objective and outcome of university education.

\section{5}

\section{Conclusion}

The objective of this paper was to determine whether the outcomes of the recently introduced SAICA Ethics syllabus match the objectives of the said module. By introducing a TeachingLearning Competency Framework for teaching applied ethics, a theoretical framework was created within which the objectives and outcomes of the Ethics syllabus could be critically compared. It was found that the objectives and outcomes matched each other to a large extent, but two notable discrepancies were identified. The first discrepancy was that, although no managerial competency objectives had been formulated, the outcomes of the syllabus nevertheless emphasised managerial competence. The second discrepancy was that, although the objectives of the syllabus did in fact emphasise behavioural competence, no such outcomes had been stipulated. It is therefore recommended that SAICA attend to these discrepancies in future revisions of their educational requirements.

\section{Bibliography}

1 ADAMS, J.S.; HARRIS, C \& CARLEY, S.S. (1998) "Challenges in teaching business ethics: using role set analysis of early career dilemmas", in Journal of Business Ethics, 17(12): 1325-1335.

2 ANDERSON, J. (1997) "What cognitive science tells us about ethics and the teaching of ethics", in Journal of Business Ethics, 16: 279-291.

3 ARMSTRONG, M.B. (1990) "Professional ethics and the accounting profession", in Business and Professional Ethics Journal, 9(2): 181-191.

4 BERGER, J. \& PRATT, C.B. (1998) "Teaching business ethics - communication ethics with controversial films", in Journal of Business Ethics, 17(16): 1817-1823.

5 BINNS, P. (1994) "Ethical business: Thinking thoughts and facilitating processes", in Business Ethics: A European Review, 3(3): 174-179.

6 BUNKE, H.C. (1988) "Should we teach business ethics?”, Business Horizons, 31(July-August): 2-8.

7 COLES, R. (1989) The Call of Stories: Teaching and the Moral Imagination. Houghton Mifflin: Boston.

8 COLES, R. (1995) "The disparity between intellect and character", The Chronicle of Higher Education, September 22: A68.

9 FUDGE, R. \& SCHLACTER, J.L. (1999)

"Motivating employees to act ethically: An expectancy theory approach", Journal of Business Ethics, 18(3): 295-304.

10 HOSMER, L.T. (1998) "Adding ethics to the business curriculum", Business Horizons, 31(JulyAugust): 9-15.

11 IFAC (2006) Approaches to developing and maintaining professional values, ethics, and attitudes, IFAC: New York [online] available at http://www. ifac.org [accessed 6 November 2006].

12 LOEB, S.E. (1988) "Teaching students accounting ethics: Some crucial issues", Issues in Accounting Ethics, 3(2): 316-329.

13 MACLAGAN, P. (1998) Management and Morality: A Developmental Perspective. Sage: London. 
14 MAHIN, L. (1998) "Critical thinking and business ethics”, Business Communication Quarterly, 61(3): 74-78.

15 MAHONEY, J. (1990) Teaching Business Ethics in the UK, Europe and the USA: A Comparative Study. Athlone Press: London.

16 MAHONEY, J. (1999) "Cultivating moral courage in business", in Enderle, G. (ed.) International Business Ethics: Challenges and Approaches: 249259, University of Notre Dame Press: Notre Dame.

17 MCDONALD, G.M. AND DONLEAVY, G.D. (1995) "Objections to the teaching of business ethics", Journal of Business Ethics, 14(11): 839-853.

18 NIELSEN, R.P. (1998) "Can ethical character be stimulated and enabled? An action-learning approach to teaching and learning organisation ethics", Business Ethics Quarterly, 8(3): 581-604.

19 PAINE, L.S. (1991) "Ethics as character development: Reflections on the objective of ethics education", in Freeman, R.E. Business Ethics: the State of the Art: 67-86, Oxford University Press: Oxford.

20 PELIKAN, J. (1992) The Idea of the University: A Re-Examination. Yale University Press: New Haven.

21 PIPER, T.R.; GENTILE, M.C. \& PARKS, S.D. (1993) Can Ethics Be Taught? Harvard Business School: Boston.

22 PROZESKY, M. (2001) Ethics in the Education of South African Chartered Accountants. (A report prepared for the South African Institute of Chartered Accountants, University of Natal: Pietermaritzburg.
23 RABOUIN, M. (1997) “Lyin' t(*)gers, and 'cares', oh my: The case for feminist integration of business ethics", Journal of Business Ethics, 16(3): 247-261.

24 ROSSOUW, G.J. (2002) "Three approaches to teaching business ethics", Teaching Business Ethics, 6(4): 411-433.

25 ROSSOUW, G. J. (2004) Developing Business Ethics as an Academic Field (BEN-Africa book series) BEN-Africa: Johannesburg.

26 SAICA. (2005) The Education Requirements of the South African Institute of Chartered Accountants for Entry into Part 1 of the Qualification Examination. SAICA: Johannesburg.

27 SHAW, W.H. (1996) "Business ethics today: A survey”, Journal of Business Ethics, 15: 489-500.

28 SIMS, R.R. (2002) "Debriefing experiential learning exercises in ethics education", Teaching Business Ethics, 6(2): 179-197.

29 SOLBERG, J., STRONG, K.C. \& MCGUIRE, C. (1995) "Living (not learning) ethics", Journal of Business Ethics, 14(1): 71-81.

30 STILES, P., AMY, J. \& LORD A. (1993) "Teaching business ethics: An open learning approach" Management Education and Development, autumn: 246-261.

31 WERHANE, P. (1999) Moral Imagination and Management Decision-Making. Oxford University Press: Oxford.

32 WHETSTONE, J.T. (1998) "Teaching ethics to managers: Contemporary problems and a traditional solution”, in Cowton, C. and Crisp, R., Business Ethics: Perspectives on the Practice of Theory. Oxford University Press: Oxford: 177-206. 